\title{
Impact of South Africa's Monetary Policy on the LNS Economies
}

\author{
Sylvanus Ikhide \\ University of Fort Hare \\ Ebson Uanguta \\ Bank of Namibia
}

\begin{abstract}
The countries in the Common Monetary Area (CMA), South Africa, Lesotho, Namibia and Swaziland, have harmonised their monetary and exchange rate policies in a quasi-monetary union since 1990. Lesotho, Namibia and Swaziland (LNS) have pegged their currencies to the South African Rand thus effectively surrendering monetary policy to the South African reserve bank. The arrangement has resulted in benefits in the form of lower prices, economy on trading costs, and a large increase in trade volume and cross-border financial transactions. However, one cost that has confronted the LNS economies in this monetary arrangement is the loss of independent monetary policy decision-making for stabilisation purposes. This study applies VAR to trace the impact of South Africa Reserve Bank ${ }^{\circ} \emptyset_{S}(S A R B)$ monetary policy on the LNS economies. Specifically, the study examines how a change in the policy instrument of the Reserve Bank of South Africa affects money, credit and level of prices in the LNS economies and consequently assesses the capability of these economies to undertake independent monetary policy. Both the impulse response functions and the cumulated forecast errors show that the lending rates, level of prices and money supply respond instantaneously to changes in the repo rate by the South African reserve bank. Our analysis confirms that the South African repo rate is the relevant policy instrument

\footnotetext{
*Corresponding address: Sylvanus Ikhide; Department of Economics, University of Fort Hare, East London Campus; PO Box 7426, East London, 5200, South Africa, Ebson Uanguta/Adrisor to Executive Director, IMF, Washington D.C. and Research Department, Bank of Namibia.

@ 2010-Center for International Economics, Sejong Institution, Sejong University, All Rights Reserved.
} 
for these economies as opposed to the LNS countries' central bank rates. The study concluded that under the existing monetary arrangement, the LNS economies may not be able to undertake independent monetary policy.

- JEL Classification: E41, E51, E52, E58

- Key Words: Monetary Policy, Transmission Mechanism, Monetary Integration

\section{Introduction}

Over the past decades, the countries in the Common Monetary Area (CMA), South Africa, Lesotho, Namibia and Swaziland, have harmonised their monetary and exchange rate policies. South Africa as a dominant and a bigger economy in the arrangement has been responsible for setting the pace and terms of changing policies in the arrangement. This arrangement has prevented the LNS (Lesotho, Namibia and Swaziland) countries from exercising any discretionary monetary policy. However, monetary policy is undertaken in South Africa with the domestic economy as the main target and to a lesser extent economic circumstances in the LNS countries. The precinct of policy has been that so long as the exchange rates of these countries are pegged to the South African Rand and as long as South Africa pursues a policy of stable and low inflation, the impact of policy will be transmitted to the LNS countries without delay and these economies will experience economic growth.

There is consensus that, over the years, the CMA arrangement has resulted in benefits in the form of lower prices, economy on trading costs, and a large increase in trade volume and cross-border financial transactions (Guma 1985, Van de Merwe 1997, Tjirongo 1998, Abedian and Matshego 2003). However, one cost that has confronted the LNS economies in this monetary arrangement is the loss of independent monetary policy decision-making for stabilisation purposes. Even as countries in this arrangement move towards deeper integration, the recurring issue on the minds of the LNS countries is their inability to target their monetary policy to their domestic disturbances, since they are forced to accept the policy chosen by the anchor currency country i.e., South Africa. In principle, the cost from the loss of independence in monetary policy formulation is greater the less correlated a country's disturbances are with the anchor country. From the Optimum Currency Area (OCA) literature, a necessary condition for the formation of a monetary union is that countries must have similar production structures so that they are affected 
similarly by exogenous shocks. In the case where countries experience asymmetric shocks, labour mobility must be high to mitigate the effects of unemployment and inflation in the two respective areas. Where these criteria are invalidated, can the countries in the arrangement still nurture the ambition of a deeper monetary union?

One major consideration in the CMA is the nature of capital flows between these countries. Capital flows freely within the CMA and principally between the LNS economies and South Africa, mostly unidirectional. This may also constrain independent monetary policy even when shocks are asymmetric and labour mobility fluid. Given the fixed exchange rate arrangement in the CMA, it is doubtful if the LNS countries can undertake independent monetary policy in the face of free capital flows.

Despite widely held views on the desirability of having monetary policy focused on domestic developments, to date, there is little empirical evidence known to the policymakers in the LNS countries with respect to the effect of South Africa's monetary policy on macroeconomic variables in their respective economies. And any argument for the withdrawal of these countries from this arrangement because of the inability to undertake independent monetary policy must be based on a demonstrated negative impact of South Africa disinflation episodes on them.

The question that this study will therefore try to address is, can the LNS economies undertake independent monetary policy under the present monetary arrangement? The paper is divided into five sections. After the brief introduction in Section 1, we discuss the experience of the LNS economies with monetary management over the years in Section II. Section III presents a brief theoretical framework and highlights some of the relevant literature. In Section IV, we employ the VAR analysis to produce both a cumulative forecast error and an impulse response analysis to trace the impact of changes in the repo rate on selected macroeconomic variables. Finally, Section V summarises our main findings and conclusions.

\section{Experience with Monetary Management in LNS Countries ${ }^{1}$}

Although the main objective of monetary policy in the LNS countries remains ensuring that the exchange rate link to the South African Rand is maintained through sufficient foreign exchange reserves and that interest rates are kept at levels which prevent any distortions to the fixed exchange rate, central banks in the

${ }^{1}$ His section borrowed from Abedian and Matshego (2003). 
LNS have devised various schemes to influence monetary policy decisions in their respective domains. For instance, in Namibia, the central bank in addition to the liquid asset requirement uses the lending and deposit facilities for commercial banks as operational tools for monetary policy. The lending facility allows the commercial banks to overdraw their account with the Bank of Namibia (BoN) after exhausting other sources of short-term funds in the market. Accommodation in this manner takes place at the Bank rate ${ }^{2}$ which is closely tied to the South African repo rate. Namibia has also been developing a liquidity monitoring and forecasting framework with the goal of influencing short-term liquidity when the situation demands such.

In Swaziland, while its objective is again to minimize interest rate differential with South Africa in order to forestall adverse capital flows, direct control over interest rate is also used in some cases to insulate the domestic economy from monetary policy actions aimed at factors specific to South Africa. Swaziland is unique among the LNS economies because it prohibits the circulation of the South African Rand in her territory ostensibly to give her some leeway in monetary management. That the South African Rand does not circulate officially in Swaziland does not preclude the free circulation of the currency in the economy. This in itself creates distortions about the definition of the money supply for monetary management purposes. Interest rates in Swaziland largely track SA's. The operational tool for the central bank to influence interest rates is the discount rate but this largely takes its direction from the repo rate in SA. However, with excess liquidity in the domestic banking system and limited domestic channels for the investment of excess liquidity, banks have traditionally looked towards the SA markets to manage their liquidity. This enforces the supremacy of SA rates over any form of domestic monetary management.

Lesotho's attempts at determining interest rate levels in relation to South Africa have undergone several stages. Before 1998, the central bank set the minimum rate to be paid on savings deposits and the prime lending rate was set at a rate slightly lower than that in SA. This administrative control of interest rates has now been phased out. Statutory reserve requirements have been lowered to encourage banks to lend to their customers. Minimum local asset requirements have been put on hold because of their ineffectiveness. Commercial banks would rather prefer to

${ }^{2}$ Bon fixes the Bank rate at 25 basis points below the repo rate. The Bank rate is supposed to be a reference point for other interest rates in Namibia but in practice, most interest rates follow closely rates in South Africa. 
hold deposits with the central bank rather than extending credit. ${ }^{3}$

In recent years the central Bank of Lesotho attempted some liquidity management as a means of curbing excess liquidity in the domestic economy through the introduction of Treasury bill auction. Treasury bills, in addition to providing opportunities for removing excess liquidity from the system, are expected to offer competitive domestic investment opportunities for banks, which should prevent the outflow of capital in search of higher returns and deplete foreign exchange reserves. Once excess liquidity is absorbed through open market transactions, banks could finance their needs in the inter-bank market and approach the central bank as lender of last resort. Accommodation takes place at the Lombard rate, which is priced, at a margin above the 91-day TB rate. Commercial bank interest rates should in theory adjust to changes in the Lombard rate. The result of these changes has not been very encouraging. Lending rates in Lesotho like other LNS countries are still higher than in South Africa. On the other hand, deposit rates in SA are higher than in LNS countries, with the result that deposits mostly flow to SA. Institutional borrowers still prefer to borrow from SA and the spread between lending and deposit rates are higher in LNS than in SA.

The results of attempts to re-focus domestic monetary policy to domestic developments in the LNS have not been successful. Wide interest rate differentials and worsened capital outflows at certain times continue to be sources of frustration to the central banks (Abedian and Matshego, 2003).

\section{Theoretical Framework and Literature Review}

In the 1970s, it was realised that the membership of a monetary union would be identical with the loss of monetary policy autonomy. This, it is argued, could be quite unsettling especially where countries do not suffer from similar shocks. Mundell's seminal article (1961), argued that the standard criterion for a natural currency area is that participating countries should be affected similarly by disturbances and should have a high degree of factor, specifically, labour mobility across countries. The asymmetric shocks debate has since then received a lot of attention in the literature

The cost of giving up monetary independence is lower the higher the association

\footnotetext{
${ }^{3}$ This is a common feature in LNS countries as banks argue that there are no bankable projects in the economy. Ikhide (2004) has actually argued that in the case of Namibia, this is due more to the absence of an adequate legal structure for the recovery of debt and risk averseness of commercial banks.
} 
of shocks (both demand and supply) between the client and the anchor. The more the shocks are related, the more policy selected by the anchor will be appropriate for the client as well. The key problem the literature had to deal with for a long time was the identification of shocks, since shocks are not variables for which data is readily available. Several methodologies have been used. For example the decomposition of series into trend and cycles leads to the measurement of business cycle similarities or differences across countries as a measure of the similar or dissimilar structure of shocks. Furthermore, the introduction of VAR methodology has gone into more detail, by decomposing shocks into supply and demand components. Finally, cross-country regression methods are used to distinguish country-specific (idiosyncratic) shocks from others. However, most of the studies in this area have been for developed countries, following the methodology adopted by Bayoumi and Eichengreen (1992) especially for the EMU (see for instance Calmfors et al., 1997; Janson, 1997; or Melitz, 1997).

The paucity of studies for developing countries is one main motivation for this study. Previous studies using VAR model to analyze asymmetric shocks in West Africa include (Houssa, 2004; Fielding and Shield, 2001, 2003). Fielding and Shield (2001) identify output and price shocks for the CFA franc zone countries and Kenya. Using a 4-variable (output growth, inflation, money growth and foreign inflation), VAR model, they found a high degree of correlation between inflation shocks of CFA franc members but not with Kenya. They also found that correlation of output across countries was not uniform. They found positive correlation for Benin, Burkina Faso, Senegal, Togo, Niger, Cameroon, Gabon, Central African Republic, and Chad while for others the correlation was not very visible. They extended this study to WAMZ (2003) using a 3-variable model (output growth, real exchange rate and money growth) and the same methodology but with the terms of trade as an exogenous variable. The results showed less real exchange rate volatilities for CFA countries and negative output shocks correlation, although the latter result is not significant.

Houssa (2004) attempted to overcome some of the shortcomings identified with some of the earlier works especially the use of the VAR model. In particular, the VAR model assumes that the shocks and the impulse response function are fundamental, i.e. they are innovations to the variables included in the system. This might not be the case. This, together with the problem of degrees of freedom associated with VAR models (the numbers of parameters estimated with the VAR model grows with the square of the number of variables included in the system) 
and the large number of restrictions required to achieve identification forced him to adopt a different methodology. His method was based on the dynamic structural factor model to compute aggregate demand and supply shocks for West African countries. His results suggest the presence of economic costs for a monetary union in West Africa because aggregate supply shocks are poorly correlated or asymmetric across these countries. Aggregate demand shocks are more positively or less negatively correlated especially for French-speaking West African countries (except Togo and Niger).

A study by Tjirongo (1998) for SADC developed a simple autoregressive (AR) and autoregressive distributed lag (ADL) models to test the symmetry of shocks in the Southern African region. To measure the symmetry of shocks, a three-step process was adopted. First, AR and ADL models were developed and estimated to derive residuals. Furthermore, the study performed correlation tests to measure the degree of association among the shocks. The results reveal strong positive correlations between real GDP "shocks" in Southern Africa and SACU countries. For non-SACU countries Tjirongo's results show that Mauritius is closely associated with developments in South Africa. In contrast, the results show that the real GDP shocks in South Africa are not correlated with those of Mozambique, Zambia and Zimbabwe. However, although Tjirongo's empirical work tend to support the existence of correlated shocks among most countries especially the CMA countries, he argued elsewhere in the study that given the structural characteristics of these economies and the not too strong mobility of labour, shocks may be relatively asymmetric.

Guma (1985) also pursued this line of argument on dissimilar structures. Whereas the South African economy has a large manufacturing base, the other economies in the CMA are basically mineral dependent and highly undiversified. He however, argued that though this may be the case, high degree of capital mobility due mainly to financial integration may render independent monetary policy impossible (Corden, 1972, Scitovsky, 1977). Guma did not carry out any empirical work to determine the degree of financial integration in the Rand Monetary Area.

The issue of the impact of shocks on the CMA countries as well as their ability to implement independent monetary policy warrants further empirical research. Tjirongo (1995) does mention though, the impact of a spell of drought in the 1980s, which affected the LNS countries in particular, as well as the impact of economic sanctions against South Africa during the same period as examples of exogenous and policy induced shocks. Some pass-through within the CMA 
followed each of these shocks. Like Guma argued, the appreciation of the Rand in the 1980's had adverse impacts on the LNS countries. Much as Van der Merwe (1997) would agree with this, he maintains however that the benefits of a larger financial market personified by South Africa will outweigh these costs. In the same vein, a similar study by the authors recently showed that the financial sector of the LNS economies are highly integrated with the South African market making independent monetary policy impossible. ${ }^{4}$ It is necessary to determine to what extent the LNS countries have been insulated from exogenous economic shocks (especially those initiated from South Africa) as a result of being members of the CMA or have had their fortunes reversed as a result of their inability to undertake defensive monetary policy.

Another dimension to this is the shift to inflation targeting regime by South Africa. This involves setting of a quantitative inflation-target for the CPI (3-6\%) which monetary policy seeks to achieve. An inflation-target regime might represent a severe constraint on the use of monetary policy to stabilise output in the case of an adverse supply shock (e.g. an oil price shock that increases prices). To stabilize inflation around the target, interest rates may be raised with the attendant effect on output. More problematic are demand shocks which require the use of the exchange rate changes to fulfil an insurance function. In a demand shock under inflation targeting, monetary and exchange rate flexibility serve as complements (Calmfors, 1998). The overall cost of both supply and demand shocks emanating from the adoption of inflation targets by South Africa to LNS countries remain to be fully assessed.

The investigation in this study does not attempt to establish the optimality of the CMA as an optimum currency area since from the foregoing, the CMA does not meet the basic criteria for an optimum currency area. Shocks are asymmetric and labour is immobile between countries. This would tend to suggest that the LNS countries should embark on independent monetary policy to deal with idiosyncratic shocks. However, this may not be realistic under the existing arrangement. This study provides some further evidence on the practicability of the implementation of independent monetary policy by the LNS countries within the existing CMA arrangement given the existing structure of trade and capital flows.

${ }^{4}$ See Nielson, Uanguta and Ikhide (2005). 


\section{Empirical Analysis}

Our empirical analysis is undertaken in three stages. First, we do a qualitative analysis of the flow of capital within the CMA. Second, using a narrative approach, we obtain the Cumulative Forecast Errors (CFE) from a univariate forecasting equation for each principal variable in each country after a major monetary shock initiated by the South African Reserve Bank and try to assess how long it takes for impact of policy to wear out. Third, we run a VAR model for each country to determine the direction and impact of monetary policy undertaken by South Africa on key economic variables in the LNS countries and Botswana.

\section{A. Qualitative Analysis of Capital Flows between the LNS Countries and South Africa}

The degree as well as the nature of financial flows between South Africa and the LNS countries can be obtained by analysing the international financial flows relating to these countries as recorded in the financial accounts of their balance of payments. Unfortunately however, the LNS countries BOP accounts do not separate flows to South Africa from flows to other destinations (outside the CMA). We therefore relied on the data published by the Reserve Bank of South Africa (Quarterly bulletin) where capital flows by country is reported.

The financial flows into and out of the CMA are dominated by flows from and out of South Africa. South Africa accounts for close to $93.4 \%$ of the region's direct investment abroad, $99 \%$ of portfolio investment abroad and $86.5 \%$ of total foreign investment assets in the region. Virtually, all portfolio investment by foreigners in the region is directed to South Africa

Except for flows to South Africa, the flows between the LNS countries are very negligible. For instance exchange control regulation in Namibia requires that $35 \%$ of assets be used to satisfy domestic asset requirements and only $15 \%$ be invested outside the CMA. The remaining 50\% is expected to be invested in the CMA, which literarily translates into South Africa. Market (interest) sensitive instruments dominate these flows. This is not surprising given that South Africa has the largest financial market in the region and risks are relatively lower than in other LNS countries. Moreover, commercial banks in the LNS countries have South African origin. These banks have substantial transactions with their parent companies in South Africa. Other investment component of the capital account, mostly banking sector deposits constitute a major portion of the flows between the LNS and South 
Africa. Though nominal interest rates are relatively close in the CMA, the perception of country risks (exchange rate risks are virtually zero) by investors varies. The size of the SA financial market, dominance of the banking market by SA banks and country risk perception all combine to ensure this pattern of capital flow between the LNS and South Africa.

All the countries in the CMA are in the final stages of the abolishing of exchange controls. This will only reinforce the existing pattern of capital flows with the LNS countries becoming more financially integrated into the South African financial market.

\section{B. The Narrative Approach}

Essentially the methodology will help us to trace out the path of monetary policy initiated by SARB on key monetary variables in the LNS countries. The use of this approach is fairly well documented in De Fiore (1998) and Bayoumi and Morsink (1999). The approach allows the use of non-statistical, qualitative analysis in a quantitative scheme. Secondly, by limiting the analysis to those episodes where monetary authorities have not reacted to movements in output, the effects of monetary policy can be identified even if the central bank often tries to smooth output fluctuations. In this approach, we identify the disinflation episodes or restrictive monetary policy in which the monetary authority (SARB) appeared to have deliberately been willing to accept some output sacrifices by tightening monetary policy. To select the date of the shock in the first case, we will focus on the Reserve Bank's main instrument, the repo rate. ${ }^{5}$ Thereafter, a dynamic forecasting analysis is used to see how changes in the policy instrument-repo rate translate into deviations of key variables from the "normal" behaviour, after each disinflation episode. A cumulative forecast error (CFE) is derived for each variable.

$$
\Delta \ln X_{t}=\alpha+\beta t+\sum_{i=1}^{12} \gamma_{i} \Delta \ln X_{t-i}+\varepsilon_{t}
$$

The "normal" path is estimated based on a simple univariate forecasting equation, where $X_{t}$ denotes the variable in the equation, i.e. credit to the private sector, money supply, and the level of prices respectively. Forecast errors at each

\footnotetext{
${ }^{5}$ Although the goal of monetary policy by SARB has changed in recent times to inflation targeting, operationally monetary policy has continued to focus on the control of short-term rates principally the repo rate. Other short-term rates closely monitor this rate.
} 
period are given by the difference between the actual and the forecast difference of the log variable. At each period t, the overall effect of monetary tightening on $X$ is obtained by cumulating the forecast errors from the date of the monetary shock up to $t$,

$$
C F E_{t}^{x^{*}}=\sum_{i=1}^{t}\left(\Delta \ln X_{t}-\Delta \ln ^{f^{*}} X_{t}\right)
$$

Since we cumulate the first difference in log values, CFE gives the percentage deviation of the variable $X$ from its usual behaviour, $t$ periods after the beginning of the shock. The advantage in this method is that it enables us to decompose variation in the system into components due to variation in the shocks. Thus, we can directly isolate variations due to the shocks. In an impulse response function, the decomposition of the levels of the variables in the system into components due to the various shocks to these variables is summarised in the result.

Our results are summarised in Tables (2) to (7) in the Appendix. We could not produce results for Lesotho due to the absence of monthly data for most of the variables in our analysis. Two periods of monetary tightening are identified, i. e., 1994:9 and 1998:5. The discussions here focus more on the latter period because it represents a more pronounced period of monetary tightening by the South African Reserve Bank. The effect is traced through for impact on prices (CPI), money supply (M2) and private sector credit (PSC).

In Swaziland, all variables show consistent decline following tightening episode. More intense in degree of decline is CPI and the least affected is PSC. The Namibian CFE results broadly replicate the result for Swaziland. However, the intensity is deeper. Private Sector Credit (PSC) declines more intensely in 1998 than in the 1994 tightening episode. Prices show the least effect. Compared to the other CMA countries, the CFE results show that Namibia is more intensely affected by the tightening of monetary policy by SARB.

The CFE results show that South Africa from where the monetary policy stance is initiated is the least affected by the tightening episodes. CPI, M2, and PSC decline with a relatively longer lag.

The result for Botswana is instructive. Unlike the 1994 episode of tightening, the 1998 episode only has moderate effects on M2 and PSC and is relatively neutral to prices. 


\section{VAR Estimates}

Following Sims (1980), one of the main methods used in the empirical literature on transmission mechanisms has been vector auto-regression (VAR). A VAR unlike the CFE is not a single regression equation but a system of regressions with one equation for each variable in the system. Its relative attractiveness stems from a number of econometric advantages. First, compared to reduced-form simultaneous equation models, VAR models impose few a priori restrictions to achieve identification. VAR models have the advantage of allowing the historical data to tell their own story. Second, the richness and unrestricted nature of the lag structure in VAR models provide a good safeguard against a host of econometric problems, notably spurious correlation and cointegration problems.

The VAR is identified in the standard manner, using a Choleski decomposition with the ordering being the relevant central bank rate (repo rate in the case of South Africa and bank rate for Namibia, Lesotho and Swaziland), ${ }^{6}$ lending rates, the money supply, level of prices and credit to the private sector. The ordering was chosen on the basis of the empirical observation by the authors on the causality and the speed with which the variables respond to shocks, with credit to the private sector assumed to be the least responsive, and followed by prices, money supply, lending rates and finally short term rates. This is broadly in agreement with the results from the narrative approach employed above. For instance, announcement of repo rate changes by the Reserve Bank evokes commercial banks movements in lending rates within 24 hours within the monetary area. Putting the central bank rate first means we assume that this rate does not respond to any other variables within the current period, but that all other variables potentially respond to this rate contemporaneously.

Two problems were identified in the use of VAR in this study. The first has to do with the ordering of variables. The ordering of variables in a VAR has been a subject of much controversy in the literature since alternative orderings may influence the explanatory powers of our equations. Specifically, it has been argued that the importance of a given variable in terms of the extent to which its innovations influence other variables may depend critically on the (arbitrary) ordering that is chosen (Porter and Offenbacher, 1983). We were guided on imposing this particular (arbitrary) causal ordering by, first, our knowledge of the behaviour of

${ }^{6}$ We however discovered that the ordering of the variables did not alter our results. See also Morsink and Bayoumi (1999). 
these variables in the economies in our sample and second, some of the existing literature. Sims (1980), Spencer (1989) and Bauyomi and Morsink (1999) have all demonstrated that order does not seem to be very valid especially when the frequency of data is monthly.

Still on ordering, the literature is mixed as to the appropriate order when Credit to the private sector and Money supply (broadly defined) is used as innovations in a VAR. The results are sensitive to the frequency of the data, the ordering of the variables and the inclusion of other variables in the system. In particular, the ordering we have chosen apart from the conformity to empirical observation, tends to be close to the findings in the literature especially when interest rates are part of the variables in the system and the observation is monthly (Porter and Offenbacher, 1983). Finally, it must be reiterated that the purpose of this study is not to resolve the (equally important) issue of the robustness of the VAR estimation ${ }^{7}$ but explain how repo rate underlines changes in credit, money supply and level of prices in the LNS economies and hence highlight the importance of South African monetary policy for monetary arrangement in the CMA. We fully agree with Bernanke and Gertler (1995) that the impulse response functions provide more understanding of the impact of monetary policy than the statistical results.

The second issue has to do with the omission of output from the VAR equation. Several studies have drawn attention to the implications of omitted variables in a VAR (Muntaz, 2008; Surico and Castelnuovo, 2005; Bernanke at.al; 2005). Summarily, missing variables could lead to biases in the reduced form VAR coefficients. Second, this could hinder the correct identification of structural shocks. Specifically, Bernanke et al (2005) argue that if the information set use by the analyst is smaller than that employed by the central bank, then structural shocks and their responses may be mis-measured because the empirical model excludes some variables that the Central bank responds to. While acknowledging the existence of these shortcomings, we doubt their relevance for our model. First, our model focuses on the defined goal of monetary policy in the reserve currency country, South Africa, which is price stability. Second, the limited set of observations will make the inclusion of more variable problematic given the degrees of freedom difficulty that may arise. Third, in all the countries in our model, monthly data on output is not available. Finally, we do not have indications

\footnotetext{
${ }^{7}$ This also explains why we have not reported the VAR estimates and the associated statistical measures of robustness since the objective is to trace the impact of policy on selected monetary variables through the impulse response function.
} 
that our results were compromised as a result of the omission of output.

The lag length of 12 was adopted for the countries in the sample and shows a superior performance judging from Swartz and Akaike information criteria tests. The result from the impulse response functions in (i) to (v) in the appendix demonstrate some degree of consistency for all countries. The responses are for orthogonalised innovations with ordering as shown in the charts. Orthogonalisation may have some effects as shown by the rather high correlations reported in Table 1 in the appendix. This should be expected given that the LNS countries belong to the same monetary area. However, as observed from the charts, initial heights of off-diagonal responses are seldom far from zero and thus one could safely interpret the results with some caution. The response graphs in a given row all have the same scale with the maximum and minimum heights shown on any graph in the row represented at the left.

The impulse response function shows a significant and contemporaneous effect of repo rate changes on lending rates in all countries. It is instructive to note that the effect of changes in the South African repo rate on lending rates of the LNS countries is by far more significant than the effect of the reference LNS central bank rates (not reported). In other words, the relevant policy rate is the repo rate and not the LNS central banks' rates. In Swaziland, a one-time standard deviation shock on the South African repo rate causes an initial increase in the lending rate. In Namibia, it causes a very sharp increase in lending rates deeper than what is observable for Swaziland but takes longer to wear off compared to the rest of the CMA economies. For Lesotho, the result is basically the same, although it initially dips before rising. Bank lending rates in the LNS economies respond very strongly to changes in the repo rate in South Africa.

Money supply declines in Namibia in response to innovations in the repo rate and continues steadily till about the tenth month. Price level initially increases though slightly before taking a downward trend Though money supply initially declines in response to the tightening of the repo rate in Swaziland, the effect wears off in the sixth month. In Lesotho, money supply also declines rapidly in response to a shock in the repo rate. We observe a significant decline in money supply in South Africa after the shock to repo rate and this continues till about the sixth month.

It is important to observe the response of level of prices to a one standard deviation shock in repo rate given the primacy of prices in the objective function of the South African monetary policy framework. The LNS countries are unanimously agreed that a major fall-out from the union is the lower prices they enjoy from South Africa. In 
Namibia, the level of prices only begins to respond to the shock in repo rate at about the second period and declines consistently thereafter. The behaviour of level of prices in response to a one-time standard deviation shock on the South African repo rate is instantaneous and very significant in Swaziland. The behaviour in Lesotho with regard to level of prices is noteworthy. ${ }^{8}$ There is a sharp decline in level of prices following a one-time standard deviation shock on the repo rate. In South Africa itself, the level of prices initially rises in response to a one-time standard deviation shock on the repo rate. This soon wears off and starts to decline sharply after the initial shock.

The response of credit to the private sector to a shock on the repo rate is quite significant in Namibia. It declines almost instantaneously and continues with this trend throughout the period. In Swaziland and Lesotho, there is no discernible trend while in South Africa, it initially takes a deep plunge but recovers after the third month and maintains a constant trend throughout the period.

The impulse responses analysis is also applied to the only non-CMA country in our sample-Botswana. Broadly from the impulse response analysis the results shows that monetary policy tightening in South Africa does have some effects on the selected variables in Botswana. In Botswana, the level of prices essentially rises after the initial shock to the repo rate and persists till about the sixth month before it begins to fall. Both money supply and private sector credit show a weak response to a shock on the repo rate in SA. Lending rates initially rise but start to decline after the third period, unlike the effects observed for the LNS countries. Thus, the co-movements in repo rate and lending rates observed for the LNS countries are not observed for Botswana. ${ }^{9}$

The results of the VAR replicate our findings for the CFE reported earlier. The response of level of prices, money supply and credit to the private sector to the tightening episodes especially the 1998 as reported by the CFE show a decline. More importantly, the decline in level of prices and money supply as a result of the tightening episode is faster and deeper than credit to the private sector.

Given these results we can tentatively conclude that monetary policy impulses

\footnotetext{
${ }^{8}$ The results from Lesotho should be interpreted with caution, as the data is annual unlike the monthly data used for the other countries.

${ }^{9}$ Nielsen, Uanguta and Ikhide (2005) report similar results. Testing the uncovered interest parity between South Africa and the LNS countries as well as Botswana, Zambia, and Zimbabwe, they found that the LNS countries are financially integrate with South Africa but found no evidence of financial integration for Botswana, Zambia and Zimbabwe.
} 
(changes in the repo rate in South Africa) are transmitted through the lending rates, money supply, private sector credit to level of prices in the CMA. Although the exact channel may not be fully established, repo rate changes do impact on price level changes in these economies. This phenomenon explains the convergence of inflation between South Africa and the LNS economies. The second conclusion is the fact that the effects vary from country to country. ${ }^{10}$ From our results, the various channels are more intense for Namibia and Swaziland and less for Lesotho. Botswana's inflation does not display the expected spontaneous response to the innovations on the repo rate.

\section{Conclusion}

This study attempted to answer the question whether the LNS economies can undertake independent monetary policy under the present CMA arrangement. Given that shocks across the CMA is asymmetric and labour mobility is highly circumscribed, the arrangement will not qualify as an archetypal monetary union. However, the LNS economies exchange rate is pegged to the South African rand and capital flow is uninhibited between the countries. Interest rates in the LNS cannot deviate substantially from the rates in South Africa and as a result the relevant central bank rate is the anchor currency policy rate. Our review in Section II shows the various efforts the monetary authorities in the LNS economies have made to undertake some form of monetary policy and the not so encouraging results.

Thus, this study evaluated the impact of SA Reserve Bank monetary policy on the LNS countries. Specifically, the study investigated the effect of changes in the SARB monetary policy tool, the repo rate on selected variables in the economy. Our results established that the LNS countries are affected by SARB monetary policy as demonstrated by the effect of monetary tightening on major monetary variables such as Money supply, Private Sector Credit, and Prices. Given the nature of capital flows in the CMA, it would appear that the relevant central bank policy rate is the South African Reserve Bank repo rate. The strong impact the repo rate exerts on lending rates, money supply and credit may render such domestic policies ineffective.

\footnotetext{
${ }^{10}$ This conclusion broadly agrees with the results obtained by Wang, Masha, Shirono and Harris (2007). They tested for price convergence among the CMA countries and concluded that there is clear evidence of long-run price convergence in the CMA. The immediate (same quarter) pass through from South African inflation to that of the LNS countries is quite large with coefficient ranging between 0.62 and 0.82 .
} 
On the surface, given the asymmetry of shocks, the LNS countries might be able to undertake independent monetary policy by for instance cutting the central bank reference rate to stimulate the economy in a depression. Under such strategies, other things equal, capital would flow out of the LNS economies causing their currencies to depreciate against the Rand. However, because of the fixed exchange rate arrangement, the currencies cannot depreciate. The monetary authorities must offset the flows by purchasing the Rand in order to keep the exchange rate unchanged. The ability of the central bank to sustain such purchases is limited by a number of factors including the amount of foreign exchange reserves held by the government.

Moreover, the experience of Botswana suggests that such independent policy may result in price and output instability (see Table 1 in Appendix). Thus, one is constrained to conclude that the optimum policy for the LNS economies is to remain within the CMA, enjoy lower prices and greater macroeconomic stability but forego the use of monetary policy for domestic economic management.

\section{Acknowledgement}

This paper is an excerpt from a study the authors undertook for the African Economic Research Consortium (AERC). The authors will like to thank the AERC for providing support for the studies. All correspondence should be addressed to the first author.

Received 25 August 2009, Revised 26 March 2010, Accepted 29 March 2010

\section{References}

Abedian I. and I. Matshego (2003), "Common Monetary Area, Situation Analysis and Policy Implications", Presentation to the CMA Governors Meeting pp. 10-11 August. Bayoumi T. and J. Morsink (1999), "The Monetary Transmission Mechanism in Japan", IMF Working Paper, Vol. 99, pp. 137.

Bayoumi, T., and B. Eichengreen(1992), "Shocking Aspects of European Monetary Unification", NBER Working Paper, No. 3949.

Bernanke, B, P. Eliasz and J Bovin (2005), "Measuring Monetary Policy. A Factor Augmented Vector Autoregressive (FAVAR) Approach", Quarterly Journal of Economics, Vlo. 120 (1), February.

Bernanke B. S. and Gertler M (1995), "Inside the Black Box: The Credit Channel of 
Monetary Policy Transmission”, NBER Working Papers, No. 5146.

Calmfors L. (1998), "Macroeconomic Policy, Wage Setting and Employment-What Difference Does the EMU Make?", Seminar Paper No. 657, Institute for International Economic Studies, Stockholm University.

Calmfors, L., Flam, H., Gortfries, N., Jerneck, M., Lindahl, R., Haaland Matlary, J., Nordh Berntsson, C., Rabiniwicz, E, and A. Vredin (1997), EMU- A Swedish Perspective, Kluwer Academic Publishers.

Castelnuovo, E, and P. Surico (2005), "The Price Puzzle and Indeterminacy”, University of Pardua and Bank of England mimeo available at: http://ideas.repec.org/p/wpa/ wuwpma/0507021.html.

Corden, W.M. (1972), Monetary Integration Princeton, N.J. Princeton University, International Finance Section.

De Fiore, F. (1998) "The Transmission Mechanism of Monetary Policy in Israel" IMF Working Paper, Vol. 98, pp. 114.

Fielding, D. and K. Shields (2001), "Modelling Macroeconomic Shocks in the CFA Franc Zone", Journal of Development Economics, Vol. 66(1), October.

Fielding, D. and K. Shields (2003), "Economic Integration in West Africa: Does the CFA Make a Difference?", Discussion Paper, No. 001, Department of Economics, University of Leicester.

Guma, X. P, (1985), "The Rand Monetary Area Agreement", 'The South African Journal of Economics', Vol. 53, No. 2, June.

Harald S. and S. Kleimeier (2006), "Interest Rates Pass-through in the CMA of the SACU Countries", The South African Journal of Economics, Vol 74(2), June.

Houssa, R. (2004), "Monetary Union in West Africa and Asymmetric Shocks: A Dynamic Factor Model Approach", The Centre for the Study of African Economies Working Paper Series, Working Paper, No. 217.

Jansen H. (1997), “Credibility of Optimal Monetary Delegation”, American Economic Review, 87.

Melitz, J. (1997), "The Evidence about the Costs and Benefits of EMU", Swedish Economic Policy Review, Vol. 4.

Mundell R. (1961), “A Theory of Optimum Currency Areas” American Economic Review. September, pp. 657-665.

Muntaz H. (2007), "Explaining the Great Stability in the UK. A Factor Augmented VAR Approach."

Nielson H., E Uanguta and S Ikhide (2005), "Financial Integration in the Common Monetary Area", South African Journal of Economics, Vol. 73(4), December.

Porter R. D., and E.K. Offenbacher (1983), "Empirical Comparisons of Credit and Monetary Aggregates Using Vector Autoregressive Methods", Economic Review, November/December.

Scitovsky, T. (1977), Economic Theory and Western Integration, London: George, Allen \& Unwin.

Spencer D. E. (1989), "Does Money Matter? The Robustness of Evidence from Vector 
Autoregressions", Journal of Money, Credit and Banking, Vol.21. No 4 (November). Sims C. A. (1980), "Comparison of Interwar and Postwar Business Cycles; Monetarism

Reconsidered", American Economic Review Papers and Proceedings Vol. 70 No 2 May.

Tjirongo, M. (1995), "Short Term Stabilisation versus Long-Term Price Stability: Evaluating Namibia's Membership of the Common Monetary Area," Center for the Study of African Economies, Institute of Economics and Statistics, WPS/95-18 (Oxford: University of Oxford).

Van der Merwe E. J. (1997), "Exchange rate Management Policies in South Africa: Recent Experience and Prospects", The Sixth Session of the Conference of African Ministers of Finance, Meeting of the Intergovernmental Group of Experts, Addis, Ababa, Ethiopia, 25-28 March.

Wang J., I. Marsha, and K. Shirono (2007), "The Common Monetary Area in Southern Africa: Shocks, Adjustment, and Policy Challenges," IMF Working Paper WP/07/158. 


\section{Appendix}

Abbreviations Used in Appendices

DRSA: Discount Rate for SA (Repo rate from 1999)

LCPI: Log of Consumer Price Index

LPSC: Log of Credit to Private sector

LM2: $\quad$ Log of Broad money Supply

LGDP: Log of Real Gross Domestic Product

LR: $\quad$ Lending rate

Table 1. Correlation Matrix

Lesotho

\begin{tabular}{cccccc}
\hline & DRSA & LR & LPSC & LM2 & LCPI \\
\hline DRSA & 1 & 0.796 & 0.418 & 0.486 & 0.402 \\
LR & 0.796 & 1.000 & 0.632 & 0.674 & 0.629 \\
LPSC & 0.418 & 0.632 & 1.000 & 0.984 & 0.997 \\
LM2 & 0.486 & 0.674 & 0.984 & 1.000 & 0.985 \\
LCPI & 0.402 & 0.629 & 0.997 & 0.985 & 1.000 \\
\hline
\end{tabular}

Namibia

\begin{tabular}{cccccc}
\hline & DRSA & LR & LPSC & LM2 & LCPI \\
\hline DRSA & 1 & 0.872 & -0.280 & -0.296 & -0.371 \\
LR & 0.872 & 1.000 & -0.584 & -0.598 & -0.667 \\
LPSC & -0.280 & -0.584 & 1.000 & 0.994 & 0.983 \\
LM2 & -0.296 & -0.598 & 0.994 & 1.000 & 0.981 \\
LCP & -0.371 & -0.667 & 0.983 & 0.981 & 1.000 \\
\hline
\end{tabular}

Botswana

\begin{tabular}{cccccc}
\hline & DRSA & LR & LPSC & LM2 & LCPI \\
\hline DRSA & 1 & -0.604 & -0.568 & -0.386 & -0.348 \\
LR & -0.604 & 1.000 & 0.845 & 0.754 & 0.733 \\
LPSC & -0.568 & 0.854 & 1.000 & 0.934 & 0.886 \\
LM2 & -0.386 & 0.754 & 0.934 & 1.000 & 0.953 \\
LCPI & -0.348 & 0.733 & 0.886 & 0.953 & 1.000 \\
\hline
\end{tabular}


Swaziland

\begin{tabular}{cccccc}
\hline & DRSA & LR & LPSC & LM2 & LCPI \\
\hline DRSA & 1 & 0.729 & -0.537 & -0.515 & -0.512 \\
LR & 0.7294 & 1.000 & -0.022 & -0.022 & -0.010 \\
LPSC & -0.5374 & -0.022 & 1.000 & 0.952 & 0.956 \\
LM2 & -0.5153 & -0.022 & 0.952 & 1.000 & 0.985 \\
LCPI & -0.5122 & -0.010 & 0.956 & 0.985 & 1.000 \\
\hline
\end{tabular}

Zimbabwe

\begin{tabular}{cccccc}
\hline & DRSA & LR & LPSC & LM2 & LCPI \\
\hline DRSA & 1 & -0.085 & -0.007 & -0.093 & -0.124 \\
LR & -0.085 & 1.000 & 0.838 & 0.810 & 0.832 \\
LPSC & -0.007 & 0.838 & 1.000 & 0.976 & 0.978 \\
LM2 & -0.093 & 0.810 & 0.976 & 1.000 & 0.995 \\
LCPI & -0.124 & 0.832 & 0.978 & 0.995 & 1.000 \\
\hline
\end{tabular}

South Africa

\begin{tabular}{cccccc}
\hline & DRSA & LR & LPSC & LM2 & LCPI \\
\hline DRSA & 1 & 0.985 & -0.315 & -0.297 & -0.278 \\
LR & 0.9852 & 1.000 & -0.326 & -0.309 & -0.292 \\
LPSC & -0.3146 & -0.326 & 1.000 & 0.998 & 0.994 \\
LM2 & -0.2974 & -0.309 & 0.998 & 1.000 & 0.993 \\
LCPI & -0.2778 & -0.292 & 0.994 & 0.993 & 1.000 \\
\hline
\end{tabular}


Table 2. Cumulative Forecast Errors for Consumer Price Index, Broad Money Supply and Private Sector Credit - Swaziland

\begin{tabular}{|c|c|c|c|c|c|c|}
\hline \multirow{2}{*}{$\begin{array}{c}\text { Months } \\
\text { After Shocks }\end{array}$} & \multicolumn{3}{|c|}{ 1994M09 } & \multicolumn{3}{|c|}{ 1998M05 } \\
\hline & CPI & M2 & PSC & CPI & M2 & PSC \\
\hline 1 & 0.020 & 0.001 & 0.016 & 0.007 & 0.030 & 0.033 \\
\hline 2 & 0.020 & $(0.043)$ & $(0.009)$ & 0.006 & 0.029 & $(0.032)$ \\
\hline 3 & $(0.002)$ & $(0.077)$ & $(0.064)$ & $(0.006)$ & 0.019 & $(0.062)$ \\
\hline 4 & $(0.010)$ & $(0.012)$ & 0.039 & $(0.011)$ & 0.002 & $(0.043)$ \\
\hline 5 & 0.002 & $(0.018)$ & 0.044 & $(0.005)$ & 0.061 & 0.006 \\
\hline 6 & 0.021 & $(0.077)$ & $(0.027)$ & 0.006 & 0.013 & $(0.007)$ \\
\hline 7 & 0.023 & 0.033 & 0.014 & $(0.002)$ & $(0.029)$ & 0.049 \\
\hline 8 & 0.010 & 0.069 & 0.012 & $(0.010)$ & 0.048 & 0.088 \\
\hline 9 & $(0.001)$ & $(0.085)$ & 0.011 & $(0.009)$ & $(0.014)$ & 0.007 \\
\hline 10 & $(0.011)$ & $(0.045)$ & $(0.053)$ & $(0.002)$ & $(0.069)$ & $(0.028)$ \\
\hline 11 & $(0.012)$ & 0.067 & $(0.028)$ & $(0.005)$ & 0.053 & 0.017 \\
\hline 12 & $(0.009)$ & 0.068 & 0.110 & $(0.008)$ & 0.050 & $(0.023)$ \\
\hline 13 & $(0.016)$ & 0.045 & 0.019 & 0.006 & $(0.009)$ & $(0.054)$ \\
\hline 14 & $(0.007)$ & $(0.037)$ & $(0.033)$ & 0.003 & 0.041 & $(0.025)$ \\
\hline 15 & 0.002 & $(0.048)$ & $(0.054)$ & $(0.009)$ & 0.035 & $(0.093)$ \\
\hline 16 & 0.001 & $(0.061)$ & $(0.072)$ & $(0.010)$ & 0.014 & $(0.061)$ \\
\hline 17 & 0.007 & (0.099) & $(0.032)$ & 0.008 & 0.013 & 0.002 \\
\hline 18 & $(0.000)$ & $(0.102)$ & $(0.052)$ & $(0.008)$ & 0.003 & 0.002 \\
\hline
\end{tabular}


Table 3. Cumulative Forecast Errors for Consumer Price Index, Broad Money Supply and Private sector Credit - Namibia

\begin{tabular}{|c|c|c|c|c|c|c|}
\hline \multirow[t]{2}{*}{$\begin{array}{c}\text { Months } \\
\text { After Shocks }\end{array}$} & \multicolumn{3}{|c|}{ 1994M09 } & \multicolumn{3}{|c|}{ 1998M05 } \\
\hline & M2 & CPI & PSC & M2 & CPI & PSC \\
\hline 1 & 0.102 & 0.019 & 0.040 & $(0.028)$ & 0.005 & 0.004 \\
\hline 2 & $(0.012)$ & 0.017 & 0.050 & $(0.022)$ & 0.012 & $(0.002)$ \\
\hline 3 & $(0.076)$ & 0.002 & 0.039 & 0.068 & 0.020 & $(0.020)$ \\
\hline 4 & $(0.004)$ & 0.006 & 0.024 & 0.041 & 0.012 & (0.028) \\
\hline 5 & 0.005 & 0.021 & 0.043 & $(0.006)$ & 0.002 & $(0.012)$ \\
\hline 6 & $(0.027)$ & 0.016 & 0.043 & $(0.007)$ & 0.000 & 0.001 \\
\hline 7 & 0.080 & 0.004 & 0.039 & $(0.009)$ & $(0.003)$ & 0.002 \\
\hline 8 & 0.100 & 0.002 & 0.034 & $(0.016)$ & 0.002 & $(0.008)$ \\
\hline 9 & $(0.006)$ & 0.003 & 0.033 & $(0.025)$ & 0.011 & 0.003 \\
\hline 10 & 0.009 & 0.005 & 0.043 & $(0.021)$ & 0.002 & $(0.013)$ \\
\hline 11 & $(0.006)$ & 0.016 & 0.033 & 0.007 & $(0.002)$ & $(0.038)$ \\
\hline 12 & 0.009 & 0.012 & 0.041 & 0.014 & $(0.001)$ & $(0.025)$ \\
\hline 13 & 0.069 & 0.007 & 0.032 & $(0.008)$ & $(0.006)$ & $(0.027)$ \\
\hline 14 & $(0.003)$ & 0.009 & 0.032 & 0.035 & $(0.000)$ & $(0.040)$ \\
\hline 15 & 0.052 & 0.002 & 0.035 & 0.043 & 0.014 & $(0.036)$ \\
\hline 16 & 0.067 & $(0.000)$ & 0.018 & $(0.017)$ & 0.010 & $(0.005)$ \\
\hline 17 & $(0.004)$ & 0.004 & 0.022 & 0.055 & $(0.003)$ & $(0.015)$ \\
\hline 18 & $(0.000)$ & 0.012 & 0.064 & 0.048 & 0.005 & $(0.013)$ \\
\hline
\end{tabular}


Table 4. Cumulative Forecast Errors for Consumer Price Index, Broad Money Supply and Private Sector Credit - South Africa

\begin{tabular}{|c|c|c|c|c|c|c|}
\hline \multirow{2}{*}{$\begin{array}{l}\text { Months After } \\
\text { Shocks }\end{array}$} & \multicolumn{3}{|c|}{ 1994M09 } & \multicolumn{3}{|c|}{ 1998M05 } \\
\hline & CPI & M2 & PSC & CPI & M2 & PSC \\
\hline 1 & 0.011 & 0.012 & 0.012 & $(0.003)$ & 0.008 & 0.030 \\
\hline 2 & 0.001 & $(0.002)$ & 0.003 & $(0.004)$ & 0.018 & 0.005 \\
\hline 3 & $(0.008)$ & 0.017 & 0.010 & 0.015 & 0.009 & $(0.005)$ \\
\hline 4 & $(0.010)$ & 0.011 & 0.006 & 0.023 & 0.001 & 0.001 \\
\hline 5 & 0.001 & $(0.045)$ & $(0.001)$ & 0.017 & 0.009 & $(0.036)$ \\
\hline 6 & 0.002 & $(0.033)$ & 0.009 & 0.010 & $(0.039)$ & $(0.033)$ \\
\hline 7 & 0.000 & 0.015 & 0.004 & $(0.007)$ & $(0.018)$ & 0.007 \\
\hline 8 & 0.009 & 0.019 & 0.000 & $(0.011)$ & 0.011 & 0.002 \\
\hline 9 & 0.002 & 0.040 & 0.000 & $(0.004)$ & $(0.035)$ & $(0.013)$ \\
\hline 10 & $(0.012)$ & 0.004 & $(0.008)$ & $(0.003)$ & $(0.068)$ & $(0.018)$ \\
\hline 11 & $(0.011)$ & $(0.040)$ & $(0.009)$ & $(0.011)$ & $(0.020)$ & $(0.011)$ \\
\hline 12 & $(0.006)$ & $(0.029)$ & $(0.007)$ & $(0.009)$ & 0.019 & $(0.017)$ \\
\hline 13 & $(0.010)$ & $(0.006)$ & 0.005 & $(0.010)$ & $(0.006)$ & $(0.007)$ \\
\hline 14 & $(0.010)$ & $(0.007)$ & $(0.002)$ & $(0.006)$ & 0.007 & 0.025 \\
\hline 15 & $(0.009)$ & 0.010 & $(0.002)$ & $(0.004)$ & 0.016 & 0.010 \\
\hline 16 & $(0.003)$ & 0.048 & 0.008 & $(0.014)$ & $(0.001)$ & $(0.017)$ \\
\hline 17 & 0.006 & $(0.017)$ & 0.002 & $(0.010)$ & 0.016 & $(0.019)$ \\
\hline 18 & $(0.001)$ & $(0.014)$ & 0.003 & $(0.004)$ & 0.015 & $(0.017)$ \\
\hline
\end{tabular}


Table 5. Cumulative Forecast Errors for Consumer Price Index, Broad Money Supply and Private sector Credit - Botswana

\begin{tabular}{|c|c|c|c|c|c|c|}
\hline Months After Shocks & \multicolumn{3}{|c|}{ 1994M09 } & \multicolumn{3}{|c|}{ 1998M05 } \\
\hline & CPI & M2 & PSC & CPI & M2 & PSC \\
\hline 1 & $(0.007)$ & 0.011 & $(0.025)$ & 0.003 & 0.031 & 0.005 \\
\hline 2 & $(0.009)$ & $(0.010)$ & $(0.004)$ & $(0.008)$ & 0.037 & 0.012 \\
\hline 3 & $(0.005)$ & $(0.039)$ & $(0.028)$ & $(0.008)$ & 0.058 & 0.056 \\
\hline 4 & $(0.005)$ & $(0.021)$ & $(0.068)$ & $(0.004)$ & 0.020 & 0.067 \\
\hline 5 & 0.001 & 0.005 & $(0.035)$ & $(0.007)$ & 0.070 & 0.035 \\
\hline 6 & 0.005 & 0.003 & $(0.026)$ & $(0.008)$ & 0.039 & 0.020 \\
\hline 7 & 0.002 & $(0.027)$ & $(0.048)$ & $(0.004)$ & $(0.037)$ & 0.033 \\
\hline 8 & 0.003 & 0.029 & 0.003 & $(0.005)$ & $(0.013)$ & 0.026 \\
\hline 9 & $(0.002)$ & 0.039 & $(0.007)$ & $(0.003)$ & $(0.008)$ & 0.032 \\
\hline 10 & $(0.000)$ & 0.011 & $(0.030)$ & 0.003 & 0.007 & 0.015 \\
\hline 11 & 0.002 & $(0.031)$ & 0.004 & 0.005 & 0.009 & 0.004 \\
\hline 12 & 0.001 & $(0.037)$ & $(0.030)$ & 0.007 & 0.003 & 0.015 \\
\hline 13 & 0.000 & 0.060 & $(0.066)$ & 0.001 & $(0.005)$ & 0.014 \\
\hline 14 & $(0.006)$ & 0.007 & $(0.066)$ & $(0.007)$ & 0.018 & 0.061 \\
\hline 15 & $(0.007)$ & $(0.069)$ & $(0.061)$ & $(0.008)$ & 0.015 & 0.078 \\
\hline 16 & $(0.003)$ & $(0.044)$ & $(0.062)$ & 0.009 & 0.013 & 0.043 \\
\hline 17 & 0.003 & $(0.022)$ & $(0.047)$ & 0.014 & 0.064 & 0.012 \\
\hline 18 & 0.002 & $(0.002)$ & $(0.006)$ & $(0.002)$ & $(0.009)$ & $(0.008)$ \\
\hline
\end{tabular}

Table 6. Cumulative Forecast Errors for Consumer Price Index, Broad Money Supply and Private Sector Credit - Zimbabwe

\begin{tabular}{|c|c|c|c|c|c|c|}
\hline \multirow[t]{2}{*}{ Months After Shocks } & \multicolumn{3}{|c|}{ 1994M09 } & \multicolumn{3}{|c|}{ 1998M05 } \\
\hline & CPI & PSC & M2 & $\mathrm{CPI}$ & PSC & M2 \\
\hline 1 & $(0.03)$ & $(0.07)$ & 0.02 & $(0.044)$ & $(0.044)$ & $(0.020)$ \\
\hline 2 & $(0.02)$ & $(0.07)$ & 0.01 & $(0.011)$ & $(0.096)$ & $(0.043)$ \\
\hline 3 & $(0.02)$ & 0.00 & $(0.11)$ & $(0.008)$ & $(0.111)$ & $(0.044)$ \\
\hline 4 & $(0.02)$ & 0.05 & $(0.09)$ & $(0.017)$ & $(0.098)$ & $(0.085)$ \\
\hline 5 & $(0.01)$ & 0.00 & $(0.10)$ & $(0.005)$ & $(0.056)$ & $(0.116)$ \\
\hline 6 & $(0.02)$ & $(0.06)$ & $(0.12)$ & $(0.014)$ & $(0.041)$ & $(0.055)$ \\
\hline 7 & $(0.03)$ & $(0.06)$ & 0.03 & $(0.030)$ & $(0.060)$ & $(0.109)$ \\
\hline 8 & $(0.04)$ & $(0.03)$ & 0.00 & $(0.030)$ & $(0.018)$ & $(0.064)$ \\
\hline 9 & $(0.06)$ & $(0.05)$ & $(0.06)$ & $(0.006)$ & $(0.087)$ & $(0.053)$ \\
\hline 10 & $(0.05)$ & $(0.01)$ & 0.05 & 0.051 & $(0.141)$ & $(0.105)$ \\
\hline 11 & $(0.04)$ & $(0.01)$ & 0.00 & 0.047 & $(0.023)$ & $(0.002)$ \\
\hline 12 & $(0.02)$ & $(0.10)$ & $(0.05)$ & 0.004 & $(0.020)$ & $(0.027)$ \\
\hline 13 & $(0.02)$ & $(0.17)$ & $(0.16)$ & $(0.014)$ & $(0.051)$ & $(0.043)$ \\
\hline 14 & $(0.09)$ & $(0.11)$ & $(0.20)$ & $(0.051)$ & $(0.056)$ & $(0.028)$ \\
\hline 15 & $(0.05)$ & $(0.06)$ & 0.05 & $(0.051)$ & $(0.125)$ & $(0.004)$ \\
\hline 16 & $(0.01)$ & $(0.12)$ & 0.00 & 0.031 & 0.002 & 0.007 \\
\hline 17 & 0.01 & $(0.09)$ & $(0.08)$ & 0.035 & 0.062 & 0.043 \\
\hline 18 & 0.01 & $(0.06)$ & $(0.03)$ & $(0.057)$ & $(0.092)$ & $(0.031)$ \\
\hline
\end{tabular}


Table 7. Cumulative Forecast Error for the Output Variable

\begin{tabular}{|c|c|c|c|}
\hline & \multicolumn{2}{|c|}{ Months After Shocks } & \multirow{2}{*}{$\frac{1998 Q 2}{\text { South Africa }}$} \\
\hline & Namibia & Botswana & \\
\hline 1 & 0.02548 & -0.00454 & 0.032309 \\
\hline 2 & -0.02156 & -0.09514 & 0.001073 \\
\hline 3 & 0.01637 & 0.041425 & 0.022751 \\
\hline 4 & -0.02257 & 0.015062 & 0.024146 \\
\hline 5 & 0.04832 & 0.014673 & 0.023617 \\
\hline 6 & -0.05514 & -0.29964 & 0.035149 \\
\hline 7 & 0.0406 & 0.125789 & 0.0249 \\
\hline 8 & -0.0279 & 0.093634 & 0.030042 \\
\hline 9 & -0.00753 & 0.012558 & 0.034511 \\
\hline 10 & -0.00168 & -0.12935 & 0.041276 \\
\hline 11 & 0.024 & 0.071916 & 0.024771 \\
\hline 12 & -0.04474 & 0.22239 & 0.027665 \\
\hline 13 & 0.00097 & -0.05014 & 0.011776 \\
\hline 14 & -0.00247 & 0.015139 & 0.013592 \\
\hline 15 & 0.01809 & 0.098522 & 0.040596 \\
\hline 16 & -0.0091 & -0.09551 & 0.04681 \\
\hline 17 & -0.01675 & -0.14276 & 0.03353 \\
\hline 18 & -0.04891 & 0.16324 & 0.020087 \\
\hline 19 & 0.03975 & -0.0787 & 0.041581 \\
\hline 20 & -0.03868 & 0.070288 & 0.008302 \\
\hline 21 & 0.07359 & -0.04271 & 0.004876 \\
\hline 22 & -0.07721 & -0.05287 & 0.019111 \\
\hline 23 & -0.00378 & 0.044047 & 0.021522 \\
\hline 24 & 0.03176 & 0.089089 & 0.030406 \\
\hline
\end{tabular}

Source: Authors own estimations

Table 8. Volatility of Inflation, Private Sector Credit and Broad Money Supply

\begin{tabular}{lccc}
\hline \multicolumn{1}{c}{ Countries } & Inflation & Private sector credit & Broad money supply \\
\hline 1.Swaziland & 0.10 & 0.21 & 0.12 \\
2. Namibia & 0.10 & 0.18 & 0.12 \\
3. Lesotho & 0.03 & 0.33 & 0.02 \\
5. South Africa & 0.08 & 0.19 & 0.19 \\
7. Botswana & 0.09 & 0.20 & 0.16 \\
\hline
\end{tabular}

Source: IFS, Calculations of Volatility (Standard Deviation) based on monthly data 
Figure1. Impulse Response for Lesotho

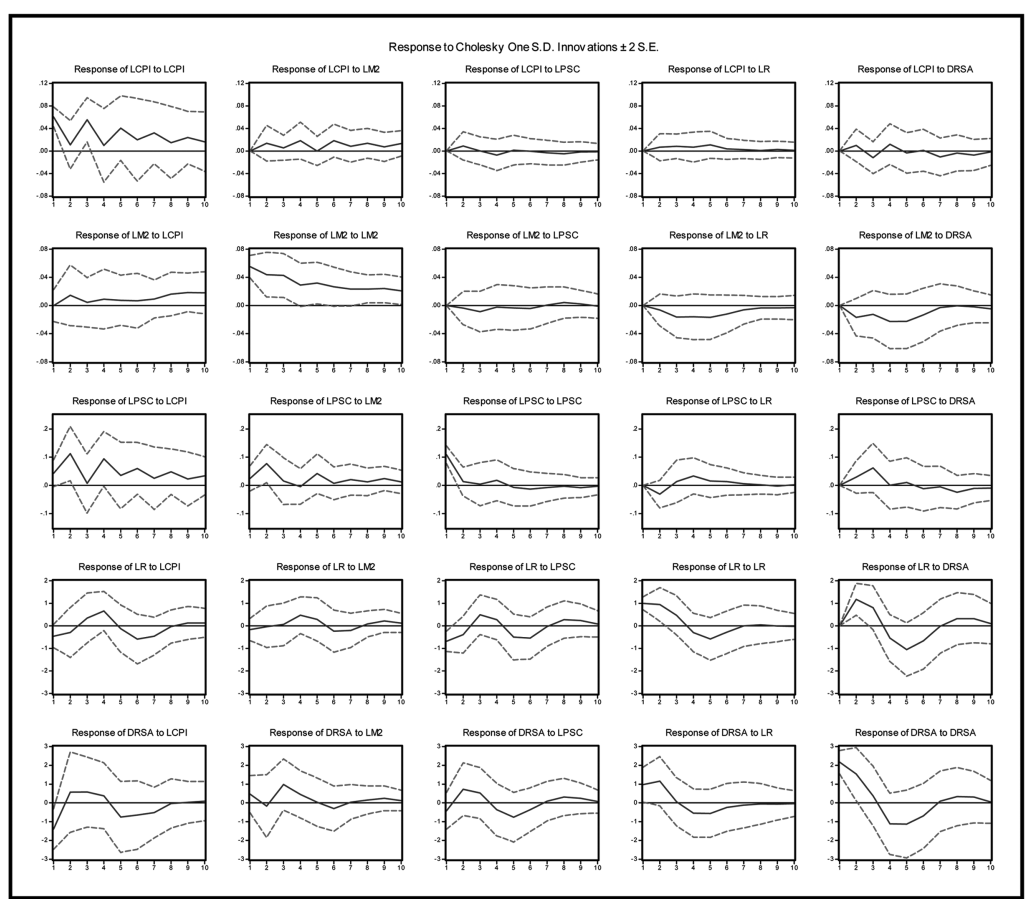

Figure 2. Impulse Response for Botswana

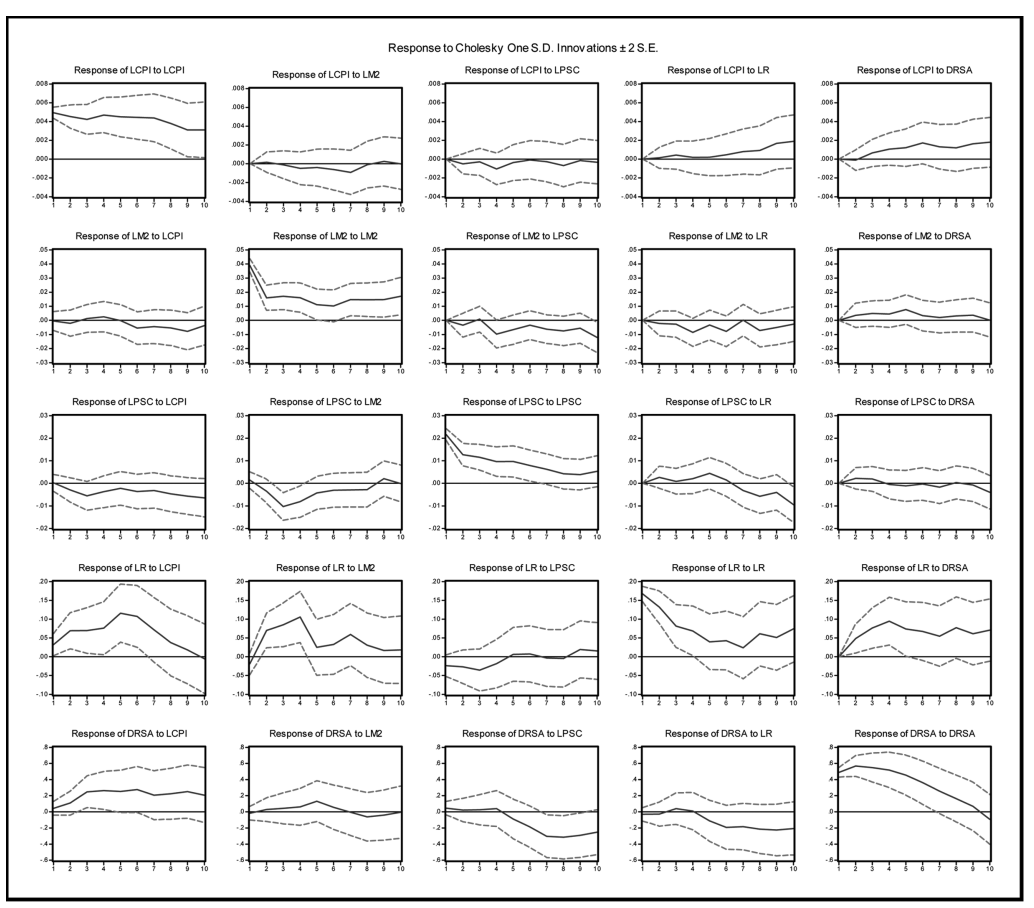


Figure 3. Impulse Response for Namibia

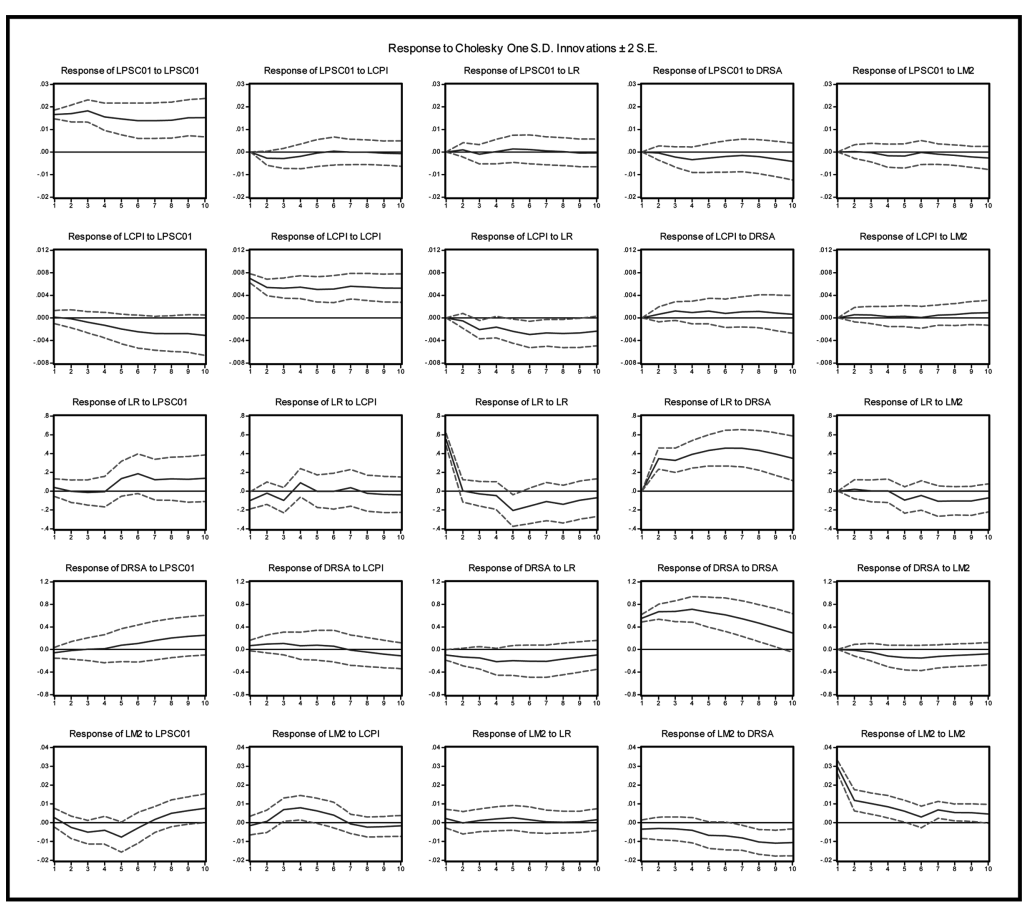

Figure 4. Impulse Responses for Swaziland

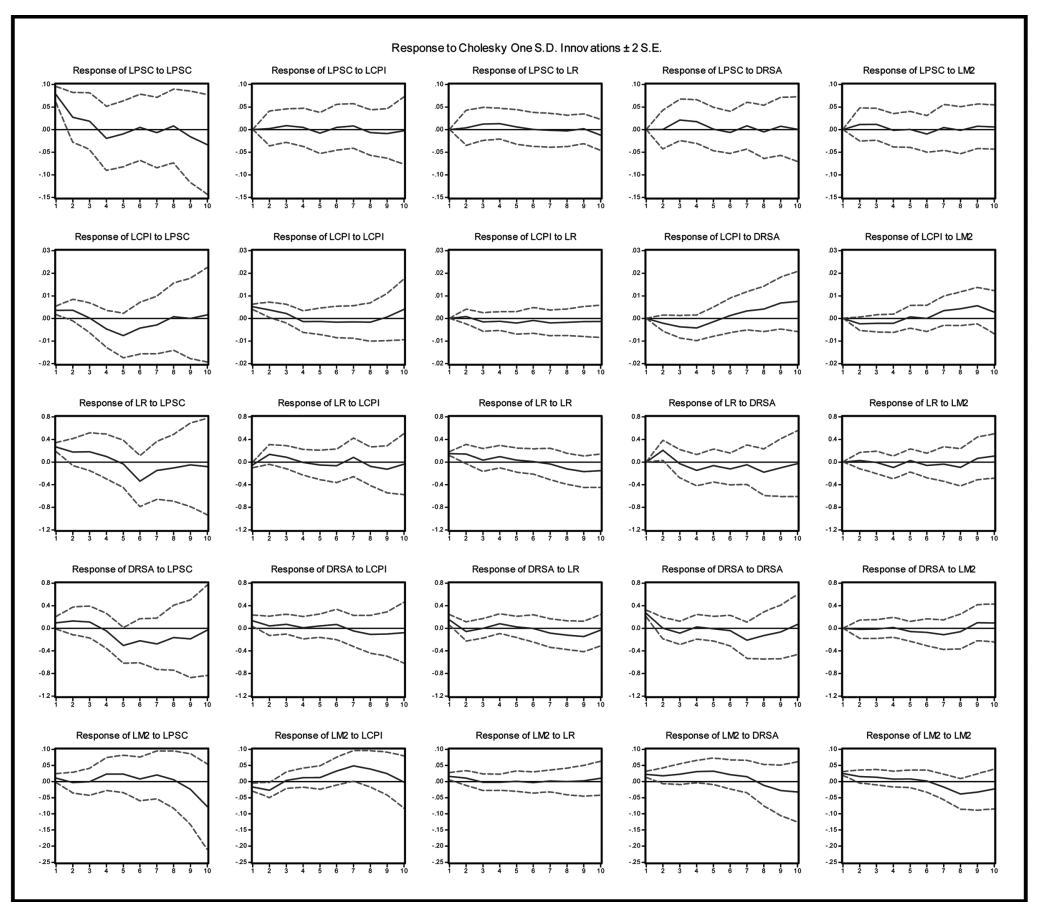


Figure 5. Impulse Responses for South Africa

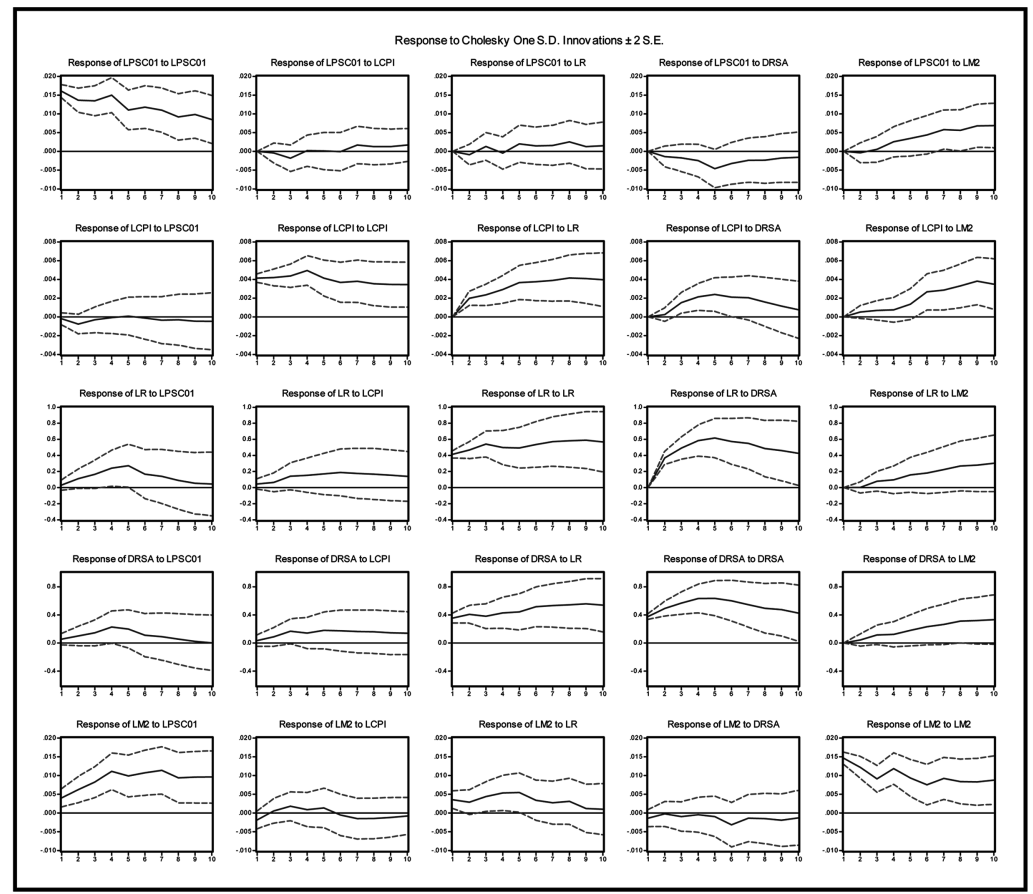

